\title{
Pengembangan Model Project Based Learning Dalam Pembelajaran Sejarah
}

\author{
Anwar Firdaus Mutawally \\ Universitas Pendidikan Indonesia \\ Anwarfirdausmutawally@gmail.com
}

Artikel ini bertujuan untuk menjelaskan model pembelajaran Project based learning (PjBL) dalam Pendidikan sejarah. Model pembelajaran PjBL sendiri sudah digunakan di negara-negara maju. Pembahasan yang akan dijelaskan pada artikel ini ialah pengertian Project Based Learning, landasan filosofis dan teoritis Project Based Learning, karakteristik model pembelajaran Project Based Learning, langkah-langkah pembelajaran Project Based Learning, peran-peran guru dan siswa dalam Project Based Learning, kelebihan dan kelemahan yang dimiliki Project Based Learning, dan Penerapan Model Pembelajaran Project Based Learning dalam Pembelajaran Sejarah.

\section{Pendahuluan}

Pendidikan merupakan suatu upaya dan usaha manusia guna mengembangkan potensi yang dimilikinya (Nurkholis, 2013). Pendidikan juga merupakan suatu proses pembelajaran yang dilakukan kepada sekelompok orang dari satu generasi ke generasi berikutnya untuk mengajarkan tentang pengetahuan, keterampilan, serta kebiasaan agar memahami perannya dimasa yang akan mendatang. Pendidikan ini dilakukan sepanjang hayat sebagai proses untuk mendewasakan manusia dan membentuk manusia yang seutuhnya. Dilihat dari perkembangan teknologi dan informasi semakin membuat kita sadar bahwa pesatnya perkembangan informasi tidak serta merta membuat batas yang kita miliki jadi hilang. Hal ini membuat peran pendidikan sebagai sarana pembelajaran untuk membentuk karakter dan pemikiran agar lebih kritis dan lebih mengajarkan kemampuan-kemampuan untuk menyaring suatu informasi.

Guru memiliki peranan penting dalam suatu pendidikan, yakni adanya tuntutan keprofesionalannya serta kemampuan pengajaran dan pendidikan yang baik. Namun dalam kenyataannya dilapangan, seringkali seorang guru memiliki beberapa kendala dalam proses belajar mengajar yang dilakukan oleh guru. Apalagi seorang guru di beberapa mata pelajaran hanya menggunakan Teknik pembelajaran satu arah dengan guru sebagai pusat informasi sehingga siswa merasa bosan terhadap pembelajaran tersebut sehingga berdampak pada penurunan prestasi siswa.

Dalam melaksanakan pembelajaran tentunya seorang guru harus bisa menyusun dan memilih model pembelajaran agar pembelajaran dilakukan tidak hanya satu arah saja. Hal ini memiliki tujuan agar siswa dapat terlibat dan merasakan situasi secara langsung dalam proses pembelajaran. Tentunya, kemampuan berfikir yang dimiliki oleh siswa dapat terasah sehingga siswa menjadi memiliki kemampuan berfikir kritis karena ia sendiri yang merasakan hal tersebut secara langsung dalam pembelajaran. Model pembelajaran juga dirasa sangat efektif dalam melakukan pembelajaran. Berbagai macam metode pembelajaran yang bermula untuk memenuhi keinginan peserta didik. dari berbagai macam model pembelajaran tersebut, terdapat model pembelajaran Project Based Learning (PjBL) yang dapat digunakan sebagai model pembelajaran sejarah. Dalam Artikel ini penulis akan membahas model pembelajaran PjBL dan aplikasinya dalam pendidikan sejarah.

\section{Pembahasan}

\section{Apa itu Project Based Learning?}

Di negara-negara maju contohnya Amerika Serikat, Project Based Learning sudah mulai diterapkan dan dikembangkan dalam proses pembelajaran. Project Based Learning berarti pembelajaran berbasis proyek. Menurut Nanang 
dan Cucu (dalam Lestari, 2015) mereka mengatakan bahwa Project Based Learning merupakan suatu pendekatan pembelajaran atau model pembalajaran yang melibatkan peserta didik agar memiliki jiwa belajar yang mandiri, kreatif, dan inovatif serta menerapkannya dalam sebuah produk yang nyata.

Project Based Learning merupakan suatu proyek yang dilakukan untuk mendalami pengetahuan dan keterampilan siswa yang diperoleh dengan cara memberikan siswa suatu permasalahan yang dapat diselesaikan dengan suatu proyek terkait dengan materi serta kompetensi yang dimiliki oleh siswa. Menurut Abidin (2014, hlm. 167) Project Based Learning merupakan model pembelajaran yang melibatkan siswa secara langsung dalam pembelajaran melalui beberapa kegiatan seperti penelitian untuk mengajarkan siswa hingga mereka bisa menyelesaikan suatu proyek pembelajaran tertentu.

Hal ini juga dikemukakan oleh Sani (2014, hlm. 172) Project Based Learning yakni strategi belajar mengajar yang digunakan dengan melibatkan siswa untuk mengerjakan proyek yang bermanfaat untuk menyelesaikan suatu permasalahan di masyarakat. Menurut Pratiwi (2015, hlm. 15) Project Based Learning adalah model pembelajaran yang digunakan untuk mendorong siswa agar aktif belajar dengan cara berkolaborasi memecahkan suatu masalah sehingga dapat merekonstruksi pembelajaran berdasarkan proyek yang dilakukan.

Project Based Learning merupakan cara pembelajaran yang bermuara pada proses pelatihan berdasarkan masalah-masalah nyata yang dilakukan sendiri melalui kegiatan tertentu (proyek). Titik berat masalah nyata tersebut dilakukan sendiri berdasarkan proyekl kegiatan sebagai proses pembelajaran dengan metode Project Based Learning (Muniarti, 2016, hlm. 373).

\section{Landasan Filosofis dan Teoritis Project Based Learning}

Dalam melaksanakan pelaksanaan, terdapat model pembelajaran yang digunakan oleh pendidik. Mmodel pembelajaran ini salah satunya adalah Project Based Learning, tentuny amodel pembelajaran ini tidak serta merta berkembang secara sendirinya. Model tersebut memiliki landasan teoritis yang melandasi model tersebut, menurut Ayukanti (2017, hlm. 12) landasan teoritis model pembelajaran Project Based Learning yakni sebagai berikut:

a. Secara teoritis, pembelajaran model Project Based Learning memiliki landasan teori belajar Konstruktivistik yang menekankan pada ide peserta didik yang membangun pengetahuan berdasarkan pengalamannya.

b. Secara Empiris, model ini dirasa sanggup membuat siswa memahami pembelajaran dengan model Project Based Learning secara bermakna dan dikembangkan berdasarkan konstruktivisme.

\section{Karakteristik Model Pembelajaran Project Based Learning}

Dalam melaksanakan pembelajaran berbasis proyek, ada suatu karakteristik yang dimiliki dari Project Based Learning. Menurut Stripling, dkk (dalam Sani, 2014, hlm. 173-174) Project Based Learning memiliki karakteristik pembelajaran yang efektif, diantaranya:

1. Mengarahkan siswa untuk menginvestigasi ide dan pertanyaan penting.

2. Merupakan suatu proses inkuiri

3. Terkait dengan kebutuhan minat siswa.

4. Berpusat pada siswa dengan membuat produk dan melakukan presentasi secara mandiri.

5. Menggunakan keterampilan berfikir kreatif, kritis, dan mencari informasi untuk melakukan investigasi menarik kesimpulan serta menghasilkan suatu produk.

6. Terkait dengan permasalahan isu dunia nyata yang autentik.

\section{Karakteristik Model Pembelajaran Project Based Learning}

Dalam melakukan pembelajaran model Project Based Learning terdapat langkah-langkah yang ditulis oleh Delise (1997, hlm. 27-35) sebagai berikut:

1. Connecting with the problem: yang dimaksudkan agar pelatih atau totor memilih, merancang dan menyampaikan masalah yang dihubungkan dengan kehidupan sehari-hari siswa yang berkaitan dengan masalah.

2. Setting up the structure: yakni peserta didik yang telah terlibat dalam masalah, 
disini ada peran pendidik dalam menciptakan struktur untuk memecahkan masalah dimana berisikan tentang rancangan tugas yang dilakukan siswa melalui proses berpikir dalam situasi yang nyata sehingga mereka dapat menemukan solusi untuk memecahkan masalah tersebut.

3. Visiting the problem: yakni sikap pendidik atau tutor yang memiliki fokus terhadap ide yang dimiliki siswa dalam menyelesaikan masalah. Fokus ini memiliki arah tujuan kepada fakta yang didapat dari solusi mereka.

4. Revisiting the problem: setelah peserta didik berkumpul didalam kelompok kecil dan menyelesaikan tugas mandirinya, mereka diskusi untuk memecahkan suatu masalah yang telah dirancang sebelumnya berdasarkan hasil pengamatan mereka.

5. Producing a product/performance and the problem: pada tahap ini dimaksudkan pendidik atau tutor meminta siswa untuk melakukan evaluasi hasil pembelajaran dari kajian masalah yang telah dikaji sebelumnya.

Menurut Abidin (2014, hlm. 172) menjelaskan tahapan yang dilakukan dalam melaksanakan Project Based Learning yakni sebagai berikut

1. Praproyek: Tahapan ini yakni suatu kegiatan yang dilakukan pendidik diluar jam pelajarana, dimana guru merancang deskripsi proyek, menentukan batu pijakan proyek, menyiapkan media dan berbagai sumber pendukung untuk belajar, serta menyiapkan situasi pembelajaran.

2. Fase 1: Identifikasi Masalah, Pada tahap ini siswa melakukan suatu pengamatan terhadap objek tertentu yang memiliki manfaat agar siswa dapat mengidentifikasi masalah dan membuat rumusan masalah.

3. Fase 2: Membuat Desain dan Jadwal Pelaksanaan Proyek. Pada tahap ini siswa bekerjasama dengan anggota kelompok serta pendidik untuk mulai merancang suatu proyek yang akan dibuat, menentukan jadwal untuk pengerjaan proyek dan melakukan persiapan lainnya.

4. Fase 3: melaksanakan penelitian, pada tahap ini siswa melakukan suatu kegiatan penelitian awal sebagai model dasar bagi produk yang akan dikembangkan oleh siswa, dimana hasil dari penelitian tersebut diperoleh data yang dikumpulkan untuk dianalisis sesuai dengan teknik analisis data yang relevan dengan penelitian.

5. Fase 4: Menyusun Draft/prototipe produk, dimana siswa mulai membuat produk sesuai dengan rencana serta penelitian yang telah dilakukan sebelumnya.

6. Fase 5: Mengukur, Menilai, dan Memperbaiki Produk. Tahap ini siswa kembali melihat produk yang akan dibuat olehnya, ditelusuri kelemahannya untuk diperbaiki. Kegiatan ini dilakukan dengan meminta pendapat serta kritik dan saran dari kelompok lain atau dengan meminta seorang pendidik.

7. Fase 6: Finalisasi dan Publikasi Produk. Tahap ini siswa melakukan suatu penyelesaian produknya setelah sesuai dengan rancangan yang telah dibuat setelah itu dipublikasikan.

8. Pascaproyek: dimana tahap ini merupakan tahapan penilaian yang dilakukan oleh pendidik, adanya penguatan, masukan serta saran untuk perbaikan produk yang telah dihasilkan oleh siswa.

\section{Peran Guru dan Siswa dalam Project Based Leraning}

Dalam (Nurohman, Tanpa tahun), menjelaskan bahwa pendidik memiliki peran sebagai fasilitator dari peserta didik apabila peserta didik mengalami kesulitan dalam pembelajaran. Selain itu, pendidik harus bisa menciptakan suasana pembelajaran yang dirasa nyaman untuk peserta didik. Dan juga harus membimbing peserta didik dalam proses pembelajaran ini agar tidak dilepas begitu saja yang menyebabkan fokus peserta didik menjadi terbagi serta mengevaluasi hasil pembelajaram yang telah dilaksanakan.

Peran peserta didik sendiri dalam pembelajaran berbasis proyek ini adalah peserta didik dapat menuangkan segala kemampuan yang mereka miliki. Peserta didik juga memiliki peran agar dapat mengatur waktu dengan baik dan sesuai. Peserta didik juga diminta agar melakukan interaksi dengan yang lainnya agar mendapatkan informasi dan hubungan yang baik dengan kelompok dalam pembelajaran ini. 


\section{Kekurangan dan Kelebihan Project Based Learning}

Abidin dalam (Nurzaman, 2016) menyebutkan apa saja kelemahan yang dimiliki Project Based Learning, yakni.

a. Pembelajaran ini membutuhkan banyak biaya

b. Pembelajaran ini membutuhkan banyak waktu

c. Membutuhkan peralatan yang tidak sedikit

d. Dalam kerja secara berkelompok, pastinya ada beberapa peserta didik yang kurang aktif dalam pengerjaan proyek

e. Dikhawatirkan apabila peserta didik hanya mampu menguasai topik yang mereka kerjakan tanpa menguasai topik yang lainnya, dan lain-lain.

Tidak hanya itu, Pembelajaran berbasis proyek ini juga memiliki kelebihan yakni.

a. Melibatkan kekreatifitasan peserta didik, sehingga peserta didik mampu berpikir secara kritis

b. Mendorong peserta didik mengembangkan kemampuan dan keterampilan yang mereka miliki

c. Peserta didik mendapatkan pengalaman dalam pembelajaran menciptakan suatu proyek

d. Mendorong peserta didik agar lebih aktif dalam proses pembelajaran

e. Pembelajaran lebih bersifat fleksibel

f. Meningkatkan kemampuan kerja sama peserta didik dalam berkelompok guna memecahkan suatu masalah, dan lain-lain.

\section{Penerapan Model Pembelajaran Project Based Learning Dalam Pembelajaran Sejarah}

Dalam melaksanakan pembelajaran sejarah kita mengenal istilah Konstruksi pembelajaran. Konstruksi ini merupakan suatu upaya untuk menghubungkan keterkaitan antara peristiwa sejarah di masa lalu dengan masalah kontemporer yang terjadi saat ini agar dapat menumbuhkan pemikiran kritis siswa dan menarik minat siswa dalam pembelajaran sejarah. Sebagaimana yang kita tau, siswa beranggapan bahwa belajar sejarah sangat membosankan dan kurang adanya manfaat yang diperoleh untuk siswa. Dengan ini Project
Based Learning merupakan suatu model pembelajaran yang cocok untuk siswa dalam merekonstruksi peristiwa masa lalu sehingga dapat menumbuhkan pemikiran kritis siswa terhadap peristiwa sejarah.

Dengan melakukan pembelajaran berbasis Project Based Learning ini membuat siswa mengasah kemampuan berfikir kritisnya sehingga ia bisa diarahkan untuk membuat suatu proyek berdasarkan peristiwa sejarah. Konstruksi yang diterapkan dalam pembelajaran dikaitkan dengan kehidupan siswa dilingkungan sekitar sehingga guru bisa menanamkan nilai-nilai sejarah kepada peserta didik, selain itu siswa pun memiliki perannya masing-masing dalam tingkatan berfikirnya sehingga pembelajaran sejarah akan lebih menarik. Untuk itu, dalam pembelajaran perlu diterapkan suatu proyek yang akan dibuat oleh siswa, seperti market place. Market Place ini merupakan suatu pembelajaran yang dilakukan dengan berkelompok yang bermanfaat untuk mendeskripsikan suatu proyek yang sudah dibuat oleh masing-masing kelompok yang berbeda satu sama lainnya, dalam pelaksanaannya masing-masing kelompok secara bergantian datang ke kelompok lain untuk mengetahui informasi yang disajikan oleh kelompok tersebut. Contoh penerapan market place dapat dilihat pada gambar 1.

Dalam penilaian yang dilakukan untuk proyek ini, selain mempertimbangkan penilaian materi, guru juga dapat memasukan unsur karakter tanggung jawab, keterampilan, kekompakan, kejujuran, komunikatif, dan semangat didalam kelompok. Penilaian ini juga dilakukan dengan penilaian antar teman disesama kelompo serta penilaian antar kelompok. Hasil penilaian tersebut dikalkulasikan untuk dimasukan kedalam penilaian siswa.

Keberhasilan pembelajaran dengan Project Based Learning berbasis Market Place ini dapat mengembangkan karakter siswa serta keterampilan siswa di dalam pembelajaran. Hal ini bermanfaat untuk siswa dalam menyusun suatu proyek berdasarkan suatu peristiwa sehingga siswa dapat ikut terjun langsung didalam proses pembelajaran. Adanya kebermaknaan di dalam pembelajaran tersebut memberikan siswa suasana belajar yang menyenangkan. Pembelajaran ini dapat menanamkan karakter pada diri siswa, selain itu juga dapat meningkatkan kemampuan belajar siswa. 


\section{“Project Based Learning berbasis Market Place”}

Kelas : $\mathrm{X}$

Materi : Kerajaan Hindu di Indonesia

Kompetensi Dasar 3.6 : Menganalisis karakteristik kehidupan masyarakat, pemerintahan, dan kebudayaan pada masa kerajaan-kerajaan Hindu-Buddha di Indonesia serta menunjukkan contoh bukti-bukti yang masih berlaku pada kehidupan masyarakat Indonesia masa kini.

Dalam materi tersebut dapat diperoleh proyek berbasis media animasi mengenai Kehidupan Kerajaan Hindu Buddha di Indonesia, maupun sesuatu hal yang terkait dengan kerajaan Hindu Buddha. Baik itu media pembelajaran, atau peninggalan kerajaan tersebut.

Sintaks (Langkah-langkah) yang perlu dipersiapkan dalam melaksanakan Project Based Learning berbasis Marketplace:

1. Praproyek: Guru membahas mengenai tujuan pembelajaran, secara sekilas menjelaskan mengenai proyek yang akan ditugaskan kepada siswa serta membantu siswa dalam menentukan ide untuk rancangan proyek yang akan dibuat.

2. Fase 1: Mencari Informasi

Siswa mencari materi-materi terkait dengan proyek yang akan dikerjakan.

3. Fase 2: Merancang proyek

Guru membantu siswa dalam membuat rancangan proyek yang akan dikerjakan oleh siswa.

4. Fase 3: Membuat jadwal pelaksaaan pembuatan proyek

Siswa membuat jadwal pelaksanaan pembuatan proyek yang nantinya diberikan ke guru untuk memantau sejauhmana siswa merancang suatu proyek tersebut.

5. Fase 4: Membuat Proyek

Siswa mulai membuat proyeknya sesuai bahasan masing-masing kelompok. Hal ini dilakukan sesuai dengan rancangan dan jadwal pelaksanaan yang sudah diputuskan sebelumnya.

\section{Fase 5: Perbaikan}

Siswa menunjukkan kepada guru tentang proyek yang sudah dibuat oleh siswa, dimana dalam hal ini peran guru yakni memberikan arahan mengenai proyek yang sudah dibuat oleh siswa, memberikan kritik dan saran untuk perbaikan proyek tersebut sehingga dapat diperbaiki oleh siswa.

\section{Fase 6: Finalisasi}

Siswa memperbaiki kembali produknya sesuai saran guru, dan melakukan penyelesaian.

\section{Fase 7: Presentation}

Pada fase ini, marketplace dilaksanakan di kelas maupun di aula sekolah. Kelompok menampilkan hasil proyeknya di kelas dengan beragam kreativitasnya, serta adanya penilaian baik itu antar teman, maupun penilaian dari guru.

9. Pascaproyek: Guru mengevaluasi hasil proyek yang sudah dibuat oleh siswa, serta memberikan masukan serta saran dari hasil proyek yang sudah disajikan oleh siswa. 


\section{Kesimpulan}

Project Based Learning merupakan suatu pembelajaran berbasis proyek yang digunakan untuk mengasah keterampilan siswa dalam memecahkan suatu masalah berdasarkan proyek pembelajaran tertentu. Pembelajaran berbasis proyek bermanfaat untuk memberikan pemahaman kepada siswa untuk mencoba merekonstruksi peristiwa sejarah berdasarkan suatu proyek agar siswa terlibat dalam pengalaman secara langsung mengenai perencanaan suatu pembelajaran yang tidak membosankan.

Selain itu juga pembelajaran berbasis proyek memiliki beberapa hambatan dan implementasi dalam segi metode pembelajaran karena memerlukan waktu yang harus disediakan lebih banyak untuk menyelesaikan masalah yang diberikan oleh pendidik secara kompleks. Sehigga pendidik dituntut untuk mempunyai kreativitas dalam pengembangan metode pembelajaran berbasis proyek. Pada pembelajaran berbasis proyek juga harus dilakukan dengan secara menyeluruh terhadap sikap, pengatahuan, dan keterampilan yang dimiliki siswa ketika melaksanakan pembelajaran berbasis proyek ini.

Dalam mata pelajaran sejarah juga dapat diterapkan pembelajaran berbasis proyek ini. Caranya dengan menghubungkan keterkaitan antara peristiwa yang terjadi di masa lalu dengan masalah kotemporer yang terjadi pada saat ini. Sehingga memunculkan pemikiran kritis dari peserta didik dan juga membuat pembelajaran sejarah lebih menarik dari biasanya.

Penulis menyadari masih banyak kekurangan dalam penulisan artikel ini, baik materi maupun struktur penulisan. Kritik dan saran membangun sangat saya butuhkan untuk menunjang perbaikan penulisan kedepannya.
Terimakasih kepada semua pihak yang telah berkontribusi dalam pembuatam artikel yang belum sempurna ini.

\section{DAFTAR PUSTAKA}

Abidin, Y. (2014). Desain Sistem Pembelajaran Dalam Konteks Kurikulum 2013. Bandung: PT Refika Aditama.

Ayukanti, Sefta. (2017). Pengaruh Model Pembelajran Project Based Learning Terhadap Hasil Belajar Peserta Didik Kelas IV Min 9 Bandar Lampung. [Skripsi]. Pendidikan Guru Madrasah Ibtidaiyah Fakultas Tarbiyah dan Keguruan Universitas Islam Negeri Raden Intan Lampung. Diakses Melalui http://repository.radenintan.ac.id/1914/4

Delise, R. (1997). Used Problem Based Learning in The Clasroom. USA: Association For Supervision and Curriculum Development.

Lestari, Tutik. (2015). Peningkatan Hasil Belajar Kompetensi Dasar Menyajikan Contoh-contoh Ilustrasi dengan Model Pembelajaran Project Based Learning dan Metode Pembelajaran Demonstrasi bagi Siswa Kelas XI Multimedia SMK Muhammadiyah Wonosari. Diakses dari: file:///C:/Users/Lenovo/Downloads/Tutik\%20Lestari 10520244042.pdf

Murniarti, E. (2016). Penerapan Metode Project Based Learning Dalam Pembelajaran. Universitas Kristen Indonesia. Diakses Melalui http://ap.fip.um.ac.id/wpcontent/uploads/2016/03/28-Erni-Muniarti.pdf

Nurkholis. (2013). Pendidikan dalam Upaya Memajukan Teknologi. Diakses dari: file:///C:/Users/Lenovo/Downloads/530Article\%20Text-1025-1-10-20160318.pdf

Nurohman, Sabar. (Tanpa tahun). Pendekatan Project Based Learning sebagai Upaya Internalisasi Scientific Method bagi Mahasiswa Calon Guru Fisika. Diakses dari: file:///C:/Users/Lenovo/Downloads/projectbased-learning\%20.pdf

Nurzaman, Ady. (2016). Penerapan Model Project Based Learning Tipe Role Playong untuk Meningkatkan Percaya Diri dan Prestasi Belajar dalam Pelajaran IPS. Diakses dari: http://repository.unpas.ac.id/12792/5/Bab\%20II.pdf

Pratiwi, R.A. (2015). Penerapan Model Project Based Learning Berbantuan LKS Untuk Meningkatkan Aktivitas dan Hasil Belajar IPA Siswa Kelas IV SDN 1 Purworejo. [Skripsi]. Jurusan IImu Pendidikan Fakultas Keguruan IImu Pendidikan Universitas Lampung. Diakses Melalui http://digilib.unila.ac.id/11663/16

Sani, R.A. (2014). Inovasi Pembelajaran. Jakarta: Bumi Aksara. 